Petra Sijpesteijn

\title{
Establishing Local Elite Authority in Egypt Through Arbitration and Mediation
}

\begin{abstract}
Using evidence from Arabic, Coptic and Greek papyri, this paper examines the role and organization of and individuals involved in mediation in the four centuries following the mid- $7^{\text {th }}$-century Muslim conquest of Egypt. Conflict resolution, the actors involved therein and whether the process took place in an institutional framework or in a more informal environment all inform us regarding changing power relations in the province. The effect of shifting power dynamics between members of the local Egyptian elite and the incoming Muslim rulers as well as the effect this had on social organization, the position of local elites and their relations with their indigenous constituencies and the authorities will be discussed. The paper also considers what this says about modifications in Egyptian elite composition and how these modifications relate to developments at the caliphal center. Finally, the question of how the role of local elites as arbitrators can be connected to their position vis-à-vis the Egyptian population on the one hand and the empire's political center on the other is examined.
\end{abstract}

Keywords: Mediation; law; Egypt; bishops; Islamicization; Arabicization; excommunication

\section{Introduction}

In the $10^{\text {th }}$ century, the bishop of al-Ashmūnayn in central Egypt sent an incensed letter to the members of his community. Some thieves, he writes, entered the house of the widowed mother of Sawep and took one artaba (irdabb) of corn, six quarts of flax, two chickens and a cock. ${ }^{1}$ The bishop calls upon the thief or thieves, whether male or female, locals or strangers, to step forward, confess their deed and return the stolen goods. If they do not, he threatens, "God will be angry with them as He was with Sodom and Gomorra and He will bring upon

This work was supported by the European Research Council under the European Union's Horizon 2020 research and innovation programme, grant number 683194 .

1 Crum 1909, no. 267. Also discussed by Mikhail 2013, 156. There are several of such letters banning thieves, all dating to the $10^{\text {th }}$ century and written in Coptic and Arabic (e. g. Reinhardt 1897; Steindorff 1892, 37-41).

Ә OpenAccess. (C) 2020 Petra Sijpesteijn, published by De Gruyter. (cc) BY-NC-ND This work is licensed under the Creative Commons Attribution-NonCommercial-NoDerivatives 4.0 License. 
them the curses of the Apocalypse and the plagues of the book of Job and the 108th Psalm." The threats are impressively thunderous. ${ }^{2}$ But the calling down of divine wrath also draws attention to the lack of other levers at his disposal. ${ }^{3}$ The instruments he is able to draw upon to deliver justice contrast sharply with those of his contemporary Muslim counterparts, and for that matter those of his ecclesial predecessors. Moreover, this relatively minor theft, though hardly immaterial for the victim, is not something a bishop would typically busy himself with.

At the same time, it is worth asking what motivated Sawep's mother to turn to the bishop with a criminal case, technically a matter for the secular courts. Her son's name cannot be connected to a recognizable Coptic name; it seems to be a transliteration of the Arabic Shu'ayb or Sa ${ }^{\prime} b$. On the other hand, the letter, which is written in Coptic, locates the complainant very clearly in a Christian Egyptian context. The emphasis on religious punishment and the relative insignificance of the theft suggest that this was foremost a local affair. Victim and perpetrator belonged to the same community and responded to the same norms and values; they would continue to occupy the same social space after this issue was resolved. Restoration of a workable equilibrium was therefore more important than retribution. Punishment of the thief seems to have been the goal of neither the widow nor the bishop. Rather, the aim of the letter was the restitution of the stolen goods, a confession from the culprit and the maintenance of stable relations and social order within the community.

In this context the bishop probably was the best person to turn to for a quick and effective outcome. For the widow, his local prestige and personal authority would have offset his lack of formal judicial power. While he had no apparatus of practical enforcement, he had the weight and status of his traditional leadership role. For the bishop, interceding successfully on the widow's behalf could only enhance his standing. This would have been a method of problem resolution familiar to all the actors involved.

Arbitration was a favored way to resolve private disputes between two civil parties in Byzantine Egypt and it continued to be used in the Arab period. ${ }^{4}$ Local

2 See Scheerlinck forthcoming for a discussion of the terminology used in Christian excommunication letters.

3 An inability to enforce their judgments was felt by both Jewish and Christian authorities under Islam. Excommunication was their most effective and often their sole sanction (Simonsohn 2011, 141). Edmund Hayes has examined how excommunication was used by the Shi' ite imāms in relation to the above-mentioned practices; I thank him for pointing me to the discussion on Jewish and Christian excommunication.

4 Gagos/van Minnen 1994. 
elites - the economic, social and religious authorities residing in the towns, religious settlements and agricultural estates - had always played a major role therein. But whereas the notables of the estates and monasteries of Byzantine Egypt had considerable powers of detention and punishment, in Muslim Egypt force was more and more the exclusive preserve of the administration and later the courts. ${ }^{5}$ The bishop of al-Ashmūnayn could threaten and enjoin, but he could not arrest, try or sentence. The tradition of arbitration existed in parallel to the formal judicial system, not in competition with it so much as in tandem. ${ }^{6}$ This raises several questions. What does the handling of conflicts say about changing power relations in the province? What does this tell us about modifications in Egyptian elite composition, and how can these changes be linked to developments at the caliphal center? How can the role of local elites as arbitrators be connected to their position vis-à-vis the Egyptian population on the one hand and to the empire's political center on the other?

The process of dispute resolution has produced much documentary evidence in Arabic, Coptic and Greek. Making use of documents from the first four centuries of Arab rule, this article will use the linguistic conditions of the documents as well as the identity of the addressees to explore the significance of the practice.

\section{Papyri}

The papyri and paper documents from Egypt are a uniquely rich source for the study of the social make up of Egypt's local elite and how its position, role and composition changed in the early Muslim period. The Arabs used papyrus as their main day-to-day writing material, shifting to paper only in the course of the $9^{\text {th }}-10^{\text {th }}$ century. Most papyri are found in the uninhabitable deserts of Egypt outside the main centers of occupation and government where continuous habitation has disturbed or outright destroyed the archaeological record, making excavations impossible today. Conversely, the absence of rain and habitation has helped to protect the desert sites since they were abandoned some fifteen hundred years ago. Papyrus documents have been found in Fusțāt, but these remain mostly unpublished. The main supplies remain the rubbish dumps of middle Egyptian towns such as Edfū, Medīnat al-Fayyūm and al-Ashmūnayn. Hardly

5 Sijpesteijn 2018.

6 Tillier 2016. For a similar analysis of private and public (court-based) dispute resolution as part of the same legal system in Roman Egypt, see Kelly 2011, chapter 7. 
any documents survive from the 'wet' Delta, although references to this area occur.

The papyrus documents were never intended for preservation. They offer unusually direct access to the society that produced them, but the often-haphazard conditions of their excavation and conservation also offer particular challenges. The Greek, Coptic and Arabic documents can sometimes be ascribed a specific provenance from internal evidence or (when it is known) where they were found. Most of the time, though, documents were unearthed during unofficial excavations and can be ascribed no clear place of origin. Sometimes the year in which the text was written appears at the end, or an identifiable individual is mentioned who dates a document. In most cases, however, a papyrus is dated solely on the basis of palaeographical criteria and the formulae it uses-a rough method that divides the documents into large groups spanning several centuries.

Because archaeological activities on mediaeval sites in Egypt have not been systematic, let alone exhaustive, the chronological and geographic distribution of papyri and paper documents is uneven. Some areas are over-represented and others occur hardly at all. Documents can also inform us of places other than where they were found through references or discussions mentioned in them. In this paper the date and provenance of papyri are given when known, but the documents have otherwise been treated as one source body. While this might obscure some fine-grained differences, it offers enough detail to highlight several long-term historical processes.

A final consideration in terms of evidence is the linguistic situation. Starting directly after their arrival, the conquerors of Egypt used Arabic to communicate with the inhabitants of the province, along with the other two administrative languages already in use, Coptic and Greek. Arabic documentation from the first half-century of Arab rule in Egypt is, however, much less voluminous than the Coptic and Greek material. Coptic and Greek continued to be used for internal written communication outside the administration as well. With very few Arabs settled in the Egyptian countryside, most events related to non-administrative activities of the Egyptian population were mainly recorded in Coptic or Greek. Due to the lack of precise dates on non-official documents, however, most Coptic and Greek papyri that have been assigned a firm date in the Arab period originated in the chancery and its offices. Few 'private' documents have been ascribed to the Arab period. In general, moreover, the Greek non-administrative material has received much more attention than the Coptic or Arabic.

Greek continued in use as an administrative language into the $9^{\text {th }}$ century, while the use of Coptic actually increased in the administrative domain under 
the Arabs, especially in the $8^{\text {th }}$ century. The last Coptic legal documents and letters from private contexts date to the $11^{\text {th }}$ century. The use of Arabic had increased dramatically by the $9^{\text {th }}$ century, and many more Arabic documents are preserved from then on.

The increase in the production of Arabic papyrus documents spanned legal, private (i.e. commercial and personal) and administrative subjects. It is clear that the number of consumers and producers of Arabic documents in the countryside (where most papyri in our collections originate) had increased fundamentally. That does not mean that all those using Arabic documents were also speakers of Arabic. A group of Arabic legal documents from Tiutūn in the Fayyūm oasis dating to the 960s illustrates the difference. They record transactions of property between Christian inhabitants of the town, set down according to Islamic legal rules in Arabic. At the end of the documents an interesting condition is added: that the seller agreed to the sale after the document was read to him "and explained to him in Coptic (bi-l-'ajamiyya)."

In the $8^{\text {th }}$ century, administrative structures in the countryside expanded, resulting in an initial increase in the use of Coptic but eventually stimulating the spread of Arabic as well. Muslim legal infrastructures evident from the late $8^{\text {th }}$ early $9^{\text {th }}$ centuries similarly promoted the use of Arabic. Merchants and others were already active in the Egyptian countryside, but starting in the second half of the $8^{\text {th }}$ century, Arabic land-leases show Arabic speakers settling and getting integrated in the countryside at a larger and more intensive scale. The increase in the use of Arabic in documents was thus the result of the expansion of Arab Muslim institutions such as administrative offices and legal structures, an expansion that took place in response to the migration of Arabic-speaking Muslims and non-Muslims from the garrisons into the countryside. As a result, local Egyptians also began to switch to Arabic, first to interact with the new Arabic-using individuals and institutions and later for internal communication.

The question of whether these Egyptian Arabic speakers also converted to Islam, or conversely whether the increase in Arabic usage signals an expansion of Islam, remains a vexing one. It is clear that converts did not automatically switch to Arabic for their daily communications, and that in any case a linguistic change to Arabic was not necessarily the result of conversion. The adoption of Arabic, the Arabicization or even Islamicization of personal names and the use of Arabic/Muslim or monotheist expressions also cannot automatically be connected to conversion. On the contrary, documentary and material evidence

7 Frantz-Murphy 1981, no. 1; Faḥmī 1972-1973, no. 9. Frantz-Murphy 1981, no. 2 contains the same expression, but the seller is a woman. 
suggests that the majority of Egypt's population remained Christian far into the medieval period, and that the area became mainly Muslim only in the $14^{\text {th }}$ century. ${ }^{8}$

\section{Egyptian Administrators}

The Arab conquerors entering Egypt in 639 initially left native administrative structures and the personnel that staffed them largely in place. ${ }^{9}$ In the newlyfounded capital of Fusțāt, Arabs did take control, filling the highest state functions of governor, fiscal agent and chief judge ( $q \bar{a}$ dì $)$. Additionally the governor, who was only appointed for short intervals, was wholly dependent on his fellow Arab wujūh. These were the descendants of the Arabs who had conquered Egypt and now filled the other senior posts in the capital. However, army units and military officials co-operated closely with local Egyptian administrators in the rest of the province. ${ }^{10}$ Outside the capital, an overwhelming sense of continuity prevailed, and administrative and legal offices continued to function more or less as before.

The administrative organization of the province was also left intact. Five eparchies were divided into some 30 pagarchies, all headed by members of the local Christian Egyptian economic and social elite who had held similar offices under the Byzantines. The pagarchs were responsible for fiscal and administrative matters in their district, relying on village headmen (Greek meizōn; Coptic lashane) and other communal leaders to execute their orders at the community level. Five dukes headed the eparchies. They stood in the administrative hierarchy between the pagarchs and the governor's office. Both the pagarchs and the dukes had an administrative staff at their disposal. ${ }^{11}$

Continuity also characterized the experience of locals accessing the systems of redress. Local notables, administrative officers, bishops, abbots and large landowners continued to be the first recourse for legal disputes amongst the Egyptians. ${ }^{12}$ Practically speaking, with very few Arabs residing outside Fusțāt there were not many alternative avenues for conflict resolution. ${ }^{13}$

8 El-Leithy 2005.

9 Sijpesteijn 2007; Sijpesteijn 2013.

10 Such amìrs were in charge of military affairs and had administrative-financial tasks (Morelli 2010, introduction).

11 Sijpesteijn 2013, $64 \mathrm{ff}$.; Legendre 2016.

12 For the rise of Christian religious authorities in conflict resolution in the late Roman Near East, see Brown 1992 and Lamoreaux 1995. See also the late $6^{\text {th }}$-century bishops Abraham and 
A Coptic papyrus dating to shortly after the arrival of the Arabs illustrates how legal conflicts were typically resolved and the authorities involved. Its more than 285 lines record the hearings regarding a family dispute over the ownership of part of a house in Edfū. ${ }^{14}$ The petitioning party calls upon "your illustrious lordships" as arbitrators, hoping they will judge him fairly because, as he writes, "the fear of God resides in you, that you are not partial to (any) man, that you observe justice onto us, so that the Lord, Jesus Christ, may preserve you and your children for a long and peaceful time and that you end well in body, soul and spirit." The "lordships" belonged to the notables of the town and are also called "the Great Men" in Greek and Coptic papyri. ${ }^{15}$

These Egyptian notables had fulfilled a crucial role in the legal, economic and administrative organization of Egypt since Byzantine times. ${ }^{16}$ As estate-holders and otherwise economically powerful individuals they had taken over most of the public functions from the administration, not so much in competition with the central authorities but rather as a form of delegation. Bishops, estateholders and heads of villages presided over legal courts, operated prisons and maintained private guards. ${ }^{17}$ While their jurisdiction extended generally over the lands they owned, the authority of ecclesiastical office-holders also covered their religious constituency. Under the Arabs both existing estate-holders and clerical officials initially continued to play a role in the resolution of the legal conflicts of the native Egyptian population, but over time that position changed.

A first step was taken under the Sufyānids (661-684), when changes in the administrative organization of the caliphate had repercussions at the provincial level in Egypt. From the 660s documents bear witness to the establishment of semi-permanent Arab settlements in the Egyptian countryside. ${ }^{18}$ While interaction between the local population and the Arab rulers continued to be rather limited, this new Arab presence was both the result and the catalyst of social change. An increasingly centralized administration diminished the role of

Pesynthius, who played an essential role in the solving of disputes and conflicts, sometimes in cooperation with village headmen (Dekker 2018).

13 For the development of legal penal practice in early Islamic Egypt, see Sijpesteijn 2018 and the references therein.

14 Schiller 1968.

15 Sijpesteijn 2013, $155 \mathrm{ff}$.

16 Palme 2007; Schiller 1968, 89 n. 20. On the Great Men, see Sijpesteijn 2013, 152-163.

17 Sijpesteijn 2018.

18 A government postal office was established by 669 in the Fayyūm (SB VI 9232). The earliest Arabic debt acknowledgement is dated to $44 \mathrm{H} / 664-665$ CE (Bruning 2015). The earliest commercial letter dates to the $1^{\text {st }} / 7^{\text {th }}$ century and originates in al-Ashmūnayn (Rāgiib 1991). 
local officials, to the advantage of the higher-placed duke and governor. ${ }^{19}$ In general the caliphal state was more present than the late Byzantine, directly demanding contributions in kind and personnel from Egyptian communities and sending its representatives as far south as Edfū. ${ }^{20}$

The Arab military officials (amir) were removed at the level of the eparchies, making dukes (still Christian and Egyptian at this time) the most important local representatives of the Arab administration. Dukes received their orders from the capital, often traveling there in person, but could also initiate administrative and legal actions. ${ }^{21}$ Pagarchs-all still Christian Egyptians belonging to the province's social economic elite-were responsible for the local execution of legal orders from the duke, the investigation of claims brought before the duke and the making known of law-breaking in the district. ${ }^{22}$ Pagarchs could also address legal issues that arose in their district directly after having been approached by local parties or at their own initiative. ${ }^{23}$ Pagarchs could forward a conflict to the duke, while claimants could turn to the duke as a form of appeal, presumably when the treatment of the pagarch was unsatisfactory or in order to circumvent the latter entirely. ${ }^{24}$ Simultaneously, cases of private law were presented to local elite members; for example, the mother of four who writes a Cop-

19 On the position of the duke, see Legendre 2016.

20 Foss 2009.

21 For attestations of the duke of Jēme deciding legal disputes, see P.KRU 10, dating to 722 CE; P.KRU 25, dating to 722/723 CE, P.KRU 66 and 76 dating to before 722 CE. The duke of Edfū appears as a legal authority in PSI 15 1570, dating to 652, 667 or 682 CE. The duke of Fayyūm or Ikhnās appears as judge in CPR VIII 84, dating to the $7^{\text {th }}-8^{\text {th }}$ century. But see the representatives of the capital (moagaritai) sent to collect the money taxes and take care of other important matters (P.Apoll. 2). For the duke spending time in Fusțāt, see P.Apoll. 6, 9, 20, 27, 28). Tillier characterizes this period as "un système judiciaire centré sur le duché," ("pagarche," 22).

22 See the order to the pagarch Papas to forward some adversaries of a claimant who had turned to the duke's office (P.Apoll. 18).

23 For examples of pagarchs getting involved at their own initiative in legal conflicts from Edfū, see the request from pagarch Platon to his colleague Papas to look into the conflict between a female slave owner and her opponent concerning her slaves (P.Apoll. 37). Another example shows the pagarch mediating in a case between a mother and her son (P.Apoll. 61. cited in Tillier 2013, 21 n. 8). See also the letter in which a plaintiff turns to Papas concerning a right he seems to base on "a previously recorded document" (P.Apoll. 60). Other examples of pagarchs taking charge of legal affairs all date to the $8^{\text {th }}$ century and originate from different areas in the province (see below).

24 Tillier 2013, 21-22. For a similar case from the early $8^{\text {th }}$ century in which villagers whose complaint has been ignored twice by the local Arab administrator turned first to the pagarch for help and then to the governor, see Sijpesteijn 2013, nos. 1, 6. Another group of villagers complained to the governor about incorrectly imposed tax levels in the early $8^{\text {th }}$ century (P.Lond. IV 1367, dating to $710 \mathrm{CE}$, provenance Ishqūh). 
tic letter in the second half of the $7^{\text {th }}$ century asking the help of a highly-placed individual in obtaining her yearly alimony of wheat, oil, wine, a dress and a coat from her ex-husband directed probably at a religious functionary. ${ }^{25}$

An Arabic letter sent in 65 H/684-685 CE from a higher official, probably the governor, to a lower administrator (presumably located in al-Ashmūnayn where the text was found) asks him to deal with a complaint raised by a Muslim woman and illustrates how these changes in the administrative organization affected certain types of litigation. ${ }^{26}$ Although only fragmentary, the papyrus tells us that by the end of the $7^{\text {th }}$ century Muslims living in the Egyptian countryside could reach the highest legal authorities in Egypt's capital with their complaints. Whether the Muslim plaintiff was purposely circumventing local authorities, appealing a case dealt with locally first or turning for help to an authority from her own ethnic-religious background is not clear. ${ }^{27}$ At the same time, the Arab Muslim high official gives directions in this letter to his subordinate Christian Egyptian pagarch about a local affair. In other words, the governor's jurisdiction extended far into the Egyptian countryside, competing with that of local Christian Egyptian authorities.

After the administrative reforms of the second half of the $7^{\text {th }}$ century, local Christian Egyptian officials and other authorities still dealt with most legal conflicts within their constituencies and domains, occasionally involving a higher official such as the duke or directly cooperating with officials such as headmen at the village level. However, especially important cases, for example those affecting one of the few Arab Muslims living in the countryside, could reach the highest authority and be dealt with by the governor himself.

\section{The Arrival of the Arabs}

Sometime after 694, the Arab Muslim pagarch 'Ațiya b. Ju'ayd (Gr. Attias) of the Fayyūm, apparently in response to a woman's complaint about maltreatment at the hands of some village headmen, instructed the latter in a Greek letter: "Do not mistreat the female letter carrier."28

25 Till 1938, provenance not mentioned.

26 Diem 1983.

27 See Mathieu Tillier's discussion of the different possible scenarios involving similar complaints of Christian plaintiffs dealt with by the governor Qurra b. Sharīk (2015, 139-141). See below for a discussion of the Qurra letters.

28 Morelli 2014. 
This papyrus is important for several reasons. First, it is the first example of an Arab Muslim in the position of pagarch in the Egyptian countryside. Secondly, it demonstrates that Christian Egyptians began to turn to the Arab Muslim authorities for help in local conflicts. These transactions took place in Greek and Coptic, languages that continued to be used administratively, especially at the local level. The fact that in this case the woman's opponents were functionaries in the Arab Muslim system of rural control might explain why she turned to a representative of that same system rather than to a local Christian Egyptian notable. The papyrus bears witness to the new situation of the late $7^{\text {th }}$ century, whereby the relationship between Egyptian authorities and their local constituencies as well as the Muslim rulers had altered significantly as the structures of social control were increasingly centralized in Arab Muslim hands.

The net effect of the changes that took place in the organization and composition of Egypt's administration at the end of the $7^{\text {th }}$ and beginning of the $8^{\text {th }}$ century was greater centralization and bureaucratization, as well as increasing Arabicization and Islamicization. These reforms were obviously connected to empire-wide changes introduced under the Marwānid caliphs, reinforced by increased Arab settlement in the countryside. The developments extended beyond the Arab administration; in 109 H/727 CE a Greek document in the Upper Egyptian town of al-Ashmūnayn was for the first time dated according to the hijra calendar while referring to Arab Muslim authorities. ${ }^{29}$

For the administration the main change concerned the ethnic-religious background of its executors. Arab Muslim administrators started to replace Christian Egyptians in the position of duke and, somewhat later, of pagarch. These new administrators acquired greater administrative and fiscal responsibilities and rights than their Egyptian predecessors, including in the legal domain. ${ }^{30}$ Arab Muslim pagarchs dealt directly with the complaints and legal conflicts presented to them, ${ }^{31}$ and papyri attest to their roles as legal investigators, mediators and judges.

29 SPP VIII 1184, for the date, see Morelli 2010, 57. The earliest known Coptic document bearing a hijra calendar date dates to 116 H/734-735 CE (P.KRU 106 = MacCoull 2009, 166-173).

30 Sijpesteijn 2013, 102-104, $200-211$.

31 For examples of pagarchs fulfilling the role of arbitrator or legal authority, see Sijpesteijn 2013, 132-134. Cf. the pagarch supervises the settlement of a theft (P.KRU 52, dating to 733 or 735 CE, provenance Jēme); the pagarch Nājid b. Muslim (in office ca. 730) orders a lower administrator to supervise the access to water of the village that complained about having lost out on water at the expense of another community (Sijpesteijn 2013, no. 16, dating to ca. 730 CE, provenance al-Fayyūm). 
Like the woman mentioned above, who turned to the Arab Muslim pagarch 'Ațiya around 694, other Christian Egyptians found their way through the Arab Muslim administrative system to receive the legal assistance they required. Dating from the first half of the $8^{\text {th }}$ century, several Christian Egyptians residing in Upper Egypt petitioned the governor Qurra b. Sharì (in office 709-715) regarding cases involving large sums of money or valuable property. The plaintiffs seem to have all been members of Egypt's socio-economic elite and thus able to access the Arab Muslim authorities in the capital several hundred kilometers to the north. ${ }^{32}$ Both the Christian and Jewish Egyptian plaintiffs and their Arab Muslim mediators operated in the same socio-political milieu. Egypt's indigenous elite (regardless of religion) shared the same class interests as the dominant Arab Muslims, and they co-operated with the new rulers in the administrative and even military organization of the province. With the most to lose, their pragmatism generally prevailed over prejudice.

The extended jurisdiction and availability of the Arab Muslim officials as pagarchs in the Egyptian countryside soon made their services desirable at other levels of Egyptian society. The pagarch Rāshid b. Khālid (who held offices in Ihnās in 718-723), and al-Ashmūnayn (725-731), called up witnesses and questioned them in a dispute between two Christian Egyptians over a piece of land. ${ }^{33}$ The pagarch 'Abd al-Humar (who is otherwise unknown) not only ordered the Christian Egyptian litigants in a disagreement over a house to come forward, but also offered instructions on solving the conflict. As a result, a Coptic document of settlement between the parties was drawn up in 725/6 in Jēme in the presence of 'Abd al-Humar. ${ }^{34}$ Another pagarch in Jēme, a certain 'Amr, also got involved in a local property dispute on behalf of the claimant, ordering her opponent to sell her half of a house that he had inherited. ${ }^{35}$

All pagarchs fell directly under the responsibility of the governor and his financial director in Fusțāt. The main difference was that Arab Muslim pagarchsor their administrations-communicated directly and independently with individual members of the local Egyptian population. Contemporary Christian Egyptian pagarchs, on the other hand, had less latitude. Not only were most of them removed from administrative posts at the local level, the authority and respon-

32 Sijpesteijn 2013, 156.

33 CPR IV 51, provenance not mentioned. For this pagarch, see Gonis 2004, 195.

34 P.KRU 42 = MacCoull 2009, 127-129.

35 P.KRU 25, provenance Jēme, dating to 722/723 CE. Finally, in c.730 in the Fayyūm, the pagarch Nājid b. Muslim asks his subordinate 'Abdallāh b. As'ad to research a claim against two brothers and send them to him so that he can do justice to the claimant. Sijpesteijn 2013, no. 21. 
sibility of those who remained was significantly reduced. They received orders from the capital on how to handle complaints, including criminal cases presented to the governor such as theft, assault and mistreatment. ${ }^{36}$

\section{Alternative Markers of Authority}

Christian Egyptian village notables, religious leaders and estate-holders continued to be influential local socio-economic players who fulfilled an important role as executors of the administration at the village and local community level. They transmitted and executed administrative orders, including those relating to civil and penal legal cases. ${ }^{37}$ They also collected and transferred taxes and shipped goods and people demanded by the Arab Muslim authorities. While functioning as brokers and agents for the Arab Muslim administration, they additionally represented local communities upwards. They stood as guarantors for taxpayers, debtors and the accused vis-à-vis the Arab Muslim authorities. ${ }^{38}$ In the Greek, Coptic and Arabic papyri of the first half of the $8^{\text {th }}$ century they are described as "solvent," "powerful," "strong," "great” and "guarantors."

Despite all this, when compared to the late Byzantine period or the first 50 years of Arab rule, the Christian Egyptian local elite's responsibilities in the administration can only be described as drastically diminished. ${ }^{39}$ Their autonomy was reduced, as they executed tasks rather than initiated them, and they must inevitably have experienced this as an assault on their status and position.

Traces of their anxiety around such changes in status can be observed in the documentary record. In the $8^{\text {th }}$ century, the number of arbitration cases in which Christian Egyptian notables function as judges increased dramatically according to Coptic documents. ${ }^{40}$ What seems to be happening is that members of the local elite, whose position in the provincial hierarchy had been diminished with the recent administrative restructuring but who maintained positions of prestige within their own constituencies, used arbitration to compensate for their loss of influence in the official organization of the country. ${ }^{41}$ Outside the administra-

36 Sijpesteijn 2013, 210. Tillier 2013, 22-23.

37 Sijpesteijn 2013, 202-203. For village headmen involved in legal cases, see Reinfandt 2010, 661 n. 36.

38 For standing guarantor for prisoners, see Sijpesteijn 2018.

39 Sijpesteijn 2013, $200 \mathrm{ff}$.

40 See the numerous examples in MacCoull 2009.

41 Similar behavior has been observed amongst West-African tribal chiefs whose role in the law courts was drastically reduced after national independence. As a result they increased their ac- 
tive framework, where as discussed above Arab Muslim pagarchs were called upon to solve internal conflicts, Egyptians continued overwhelmingly to turn to the existing leaders of their communities using the familiar languages of Coptic and Greek.

The replacement of Christian and Jewish Egyptians as local administrators with Arab Muslims did not mean that Christians and Jews stopped playing a role in the administration. In fact the bulk of the administrative offices continued to be filled with local specialists: scribes, secretaries, fiscal collectors and all sorts of executive officers continued to be Egyptian, Christian and/or Jewish. This continued role in the administration might even explain the increase in the use of Coptic in the Muslim chancery in the $8^{\text {th }}$ century, given the close relations between the religious institutions (such as the monasteries) where these officials were trained and the Muslim administration. ${ }^{42}$ In this way clerical leaders continued to play an indirect role as well. Christians and Jews working in the Muslim administration might play a significant intermediary role for their co-religionists, although this could on occasion backfire. ${ }^{43}$ Such indirect involvement through Christian and Jewish Egyptian administrators was, however, of a markedly different order than the direct role that religious and local authorities had played before.

\section{An 'Abbāsid Revolution?}

Following the 'Abbāsid takeover in 750 another set of changes in the administrative, judicial and political organization of the province occurs in the documentation, and its repercussions for the Egyptian elite can also be seen in documents dealing with conflict resolution and informal requests for help.

The first attestation of a functioning qāệ in Fusțāt is dated to 141 H/758 - 759 CE. ${ }^{44}$ From then on references to Islamic law courts and infrastructures gradually increase in both quantity and spread. An $8^{\text {th }}$-century Arabic papyrus records a petition to a $q \bar{a} d \underline{i} \bar{i}$ in which he is asked to mediate in a conflict between several

tivities and responsibilities in arbitration, seemingly in an attempt to compensate for lost influence (I would like to thank David Ehrhardt for sharing this insight based on his current research with me).

42 Lajos Berkes made this argument in his lecture at the $7^{\text {th }}$ International Society for Arabic Papyrology congress in Berlin in 2018.

43 Simonsohn 2011, 154-155.

44 Tillier 2013, 31 ff. For other attestations of $q \bar{a} d \underline{\text { ịs }}$ in the papyri, see Sijpesteijn 2013, 403. 
siblings over their mother's inheritance of a share in a house. ${ }^{45}$ This is precisely the kind of civil dispute that would previously have been dealt with before a local authority figure. Other legal reforms were the introduction of the institution of professional witnesses ('udūl) in 174 H/790 CE by qāộ̀ Mufaḍ̣al b. Fuḍāla (in office 174-177 H/790-793 CE), which coincides with the appearance of handwritten witness signatures at the end of Arabic legal documents. This indicates the Muslim legal apparatus was beginning to operate beyond the capital. ${ }^{46}$

Arbitration remained very important, especially in civil law cases, but the increased presence of the Muslim court, with its more stable infrastructure and mechanisms of enforcement such as prisons and guards, provided a powerful alternative to local mediators. ${ }^{47}$ While some domains, especially those involving punishments under penal law, were removed from local elite jurisdiction entirely, the Christian Egyptian population played a decisive part in undermining the remnants of the old system as they progressively turned to Muslim legal instruments and institutions to solve conflicts. On the other hand, a general preference in some cases for private conflict resolution rather than a public treatment in court did not disappear. ${ }^{48}$

A shift is also visible in civil cases and requests for other kinds of help. Not only were Islamic legal structures more readily available to Egyptian plaintiffs, but a growing Arab Muslim population in the Egyptian countryside increased the opportunities for interaction between the different populations in various domains. This in its turn led to conversions amongst the local population, albeit at this time still on a small scale. It is in this context that we can understand the $8^{\text {th }}$ century Coptic papyrus in which Ibrāhīm, 'Abd al-Raḥmān Phiph, 'Abd al-Bāth, Joseph and Chael Kalthourte make a statement in front of Abū Sa'īd concerning a donkey. ${ }^{49}$ Abū Sa $\bar{i} d$, although not necessarily a Muslim, is apparently acculturated enough to have taken on an Arab kunya. The other parties involved carry partially Arabic names, sometimes in combination with a Coptic one. The deliberations concerning the conflict over the donkey were probably conducted in

\section{CPR XVI 3.}

46 Khan 1993, 173; El Shamsy 2013, 105-107. The earliest document with hand-written signatures is a debt acknowledgement dated $178 \mathrm{H} / 795 \mathrm{CE}$ (CPR XXVI 17, provenance not mentioned). 47 But see also the opposite development, the increased popularity of arbitration as an alternative for a slowly operating court system in 'Abbāsid Iraq (Tillier 2014).

48 The prolonged time that cases could sometimes take in court once there were more Muslims to use them seems to have motivated plaintiffs to turn to the more effective arbitration (Tillier 2014). Kelly lists the reasons why people turned to private conflict solution in Roman Egypt (2011, chapter 7).

49 P.KölnÄgyp II 56, provenance unknown. 
Coptic, as was the document that records the statement. Abū Sa'īd apparently held some kind of position of authority, but no official title is mentioned. From the same period comes an Arabic letter in which a request for financial help is directed to an unnamed benefactor. ${ }^{50}$

These two documents originate in two different ethnic-linguistic milieus and show Arab Muslim patrons serving Arab Muslim petitioners and Egyptians helping Egyptians, but a definite shift is detectable. Arabicized Muslim, Christian and Jewish administrative and private authorities were increasingly involved in resolving civil and criminal conflicts amongst the Egyptian population. ${ }^{51}$

\section{Turkish-Persian Influx}

The $9^{\text {th }}$ century shows a rapid increase in Arabic documentation at the expense of Greek and to a lesser extent Coptic material. In this period, Arabic became the vehicle of communication and it was in Arabic that Muslim, Christian and Jewish Egyptians turned to mediators and patrons for help. Arabicization increased through Arab settlements outside the garrison cities and an expanding Arab Muslim administration encroaching on the countryside. The number of civil and penal law cases involving both Muslims and non-Muslims-including those concerning small properties-brought before the Muslim authorities consequently grew. Moreover, the results of such cases were increasingly recorded in Arabic. $^{52}$

While the daily use of Arabic grew in Egypt, other developments taking place at the center of the empire led to a diminished position for Arab Egyptians. The descendants of the conquerors had been in charge of the main administrative positions in the capital Fustāt, gradually extending their presence and influence into the Egyptian countryside. An influx of Turkish-Persian administrators and military leaders and the appointment of Arab high officials originating from the caliphal center in Egypt eroded the position of Arab Egyptians in the province. ${ }^{53}$

50 P.Ryl.Arab. I VI 8.

51 See for example the unpublished Arabic papyrus AP 849, dating to the $8^{\text {th }}$ century CE, which records a request to oversee a failure in an exchange between three Jewish Egyptians in Arabic. I am preparing this document for publication.

52 See the petition sent by an orphaned heir, seemingly a Muslim, to the amïr Abū l-Ḥasan asking to retrieve his share of the inheritance of his father which a certain Elias, presumably a Christian, has taken (Grohmann 1952, 186-188).

53 Sijpesteijn 2016. 
The unrest following the death of caliph al-Rashīd in 809 was quelled and 'Abbāsid control secured by the general 'Abdallāh b. Ṭāhir (d. 230 H/844 CE) and his troops. His seizure of Egypt in 210 or $211 \mathrm{H} / 825-826$ CE to $212 \mathrm{H} / 827$ CE resulted in increased centralization and influence from the East. Egypt's governors were now appointed for longer periods of three to four years and therefore more independent of local Arab elites. No longer forced to rely on locals when filling the crucial positions of șāhib al-shurța, șāhib al-kharāj and qādī, governors appointed men to enact these roles from their own class of eastern military leaders. Qādìs were still Arab, but arrived from the central lands of the empire. ${ }^{54}$ The abolition of the dīwān in $218 \mathrm{H} / 833$ CE by the caliph al-Ma'mūn put a formal end to the privileged position of Arab Egyptians, but rather than a watershed this event was the last stage in a drawn-out process that steadily undermined their position and authority. ${ }^{55}$

The new eastern officials appointed to top positions brought their own entourages of officials to Egypt and these spread eastern practices into lower layers of the administration. The deteriorating political and economic situation in the capital Baghdad drove further Persian-trained administrators to Egypt in search of employment, and documents show Persian-named officials appearing with more frequency in the documentation. These officials introduced a more eastern technical terminology into the bureaucracy, as the appearance of terms such as jahbadh (cashier) or sultān (for the administration) show. ${ }^{56}$ Certain scribal practices occur for the first time in Egypt, including authentication methods and chancery scripts, and seem to be connected to customs current earlier in the eastern part of the empire. ${ }^{57}$

The lost authority of Arab Egyptians vis-à-vis Turkish-Persian immigrants found expression through different channels. The $9^{\text {th }}$-century local Egyptian history Futūh Mișr seems partially to have been written to record the deeds of Egypt's wujūh..$^{58}$ Other texts show Egypt's Muslim population developing regional affiliations as a result of local conversion and in reaction to the sidelining of Arab Egyptians. ${ }^{59} \mathrm{Al}-\mathrm{Shāfi}$ '̄’s (d. $204 \mathrm{H} / 820 \mathrm{CE}$ ) canonization of Islamic law was

54 Tillier 2012, 33.

55 Sijpesteijn 2016.

56 Frantz-Murphy 2001, 122. The earliest attestation of jahbadh dates to 259 H/874 CE (CPR XXI 61). The first attestation of sultān in an agricultural lease is dated 217 H/832 CE (Frantz-Murphy 2001, 36-39).

57 Khan 1994; Khan 2006; Sijpesteijn 2012.

58 Kennedy 1998, 66-80.

59 Sijpesteijn 2011. 
a response to a loss of Arab exclusivity amongst Egypt's expanding-through immigration and conversion-Muslim population. ${ }^{60}$

The change in ethnic identity at the top echelons of the administration and the consequent downgrading of the Arab Egyptian elite can be traced in the documents and shows striking parallels with similar developments some hundred years earlier. In the first part of the $8^{\text {th }}$ century, Arab Egyptians had risen to their prestigious position by replacing Christian Egyptians in the administration. A century later the Arab Egyptians were being replaced by Turkish-Persian officials. In a $9^{\text {th }}$-century Arabic papyrus, a farmer turns to an amir, presumably a military functionary who has arrived with the troops from the east, to ask for help paying his taxes after a bad harvest. ${ }^{61}$ In another Arabic papyrus, an immigrant (gharīb, “stranger”) asks another army leader identified as qā'id for help in getting settled in his new hometown. ${ }^{62}$ Finally, a Ṭūlūnid official is consulted by a former chancery scribe concerning a marriage. ${ }^{63}$

Contemporaneous to these letters directed to members of the new TurkishPersian military elite in their administrative functions are the numerous Arabic letters containing informal requests for help directed to unidentified individuals. ${ }^{64}$ As discussed above in the case of the Christian Egyptians, these informal Arabic-language requests suggest that Arab notables expanded their presence in the domain of private problem solving and dispute resolution when their role in public administration was diminished.

\section{Conclusion}

Christian and Jewish Egyptian community leaders continued to play a role in private dispute resolution. The letter quoted at the beginning of this article shows how a bishop could still exert power through his religious authority over transgressors in his community. The Geniza preserves plenty of examples of Jewish authorities in Fusțāt fulfilling similar functions into the medieval period. Cases that threatened community norms were especially likely to be dealt with by mediators from that community. Moreover, mediation offered a strong alternative to a complicated and expensive legal system. It was especially attractive as the

60 El Shamsy 2013, chapter 4.

61 P.Khalili I 16. See the contemporary petition directed to the amīr Abū l-Ḥasan asking for help in retrieving part of an inheritance (Grohmann 1952, 186-188).

62 P.Ryl.Arab. I I 2.

63 P.Khalili I 18.

64 E. g. Grohmann 1952, 179-180; 185-186. 
court system developed in complexity and the official system became overloaded with the growth of the Muslim population and a subsequent increase in court cases. ${ }^{65}$ Christian, Jewish and Muslim community leaders continued to serve the need of their specific constituencies, but shifts can be observed.

A connection has been made in this paper between administrative status and socio-economic elite membership. A diminished role in the administrative hierarchy had repercussions for one's social reputation and standing in the community. This becomes explicit in the way informal dispute resolution was organized and in whom the community chose as its arbitrators. An arbitrator's authority was based on a position of trust, respect and eminence in the community. While religious leaders obtained their authority from their religious institution, state officials and the infrastructure at their disposal were obvious mediators as well.

Individuals without a title and official position needed to establish their authority within society in other ways. With the loss of institutional backing as their position in the Muslim administration was downgraded, the autonomy of their religious institution was decreased or their independence lost to an increasingly centralized state, the stage of private conflict solution becomes especially attractive as a way to build and maintain a reputation. In the face of the loss of a formal position of prestige in society, an individual's presence as a mediator may be said to have increased.

\section{Bibliography}

Banaji, Jairus (2001), Agrarian Change in Late Antiquity: Gold, Labour, and Aristocratic Dominance, Oxford: University of Oxford Press.

Brown, Peter (1992), Power and Persuasion in Late Antiquity: Towards a Christian Empire, Madison: University of Wisconsin Press.

Bruning, Jelle (2015), "A Legal Sunna in Dhikr Haqqs from Sufyanid Egypt”, Islamic Law and Society 22: 1-23.

Crum, Walter (1909), Catalogue of the Coptic Manuscripts in the Collection of the John Rylands Library, Manchester: Manchester University Press.

Dekker, Renate (2018), Episcopal Networks and Authority in Late Antique Egypt: Bishops of the Theban Region at Work, Leuven: Peeters.

Diem, Werner (1983), “Der Gouverneur an den Pagarchen: Ein verkannter Papyrus vom Jahre 65 der Hiğra”, Der Islam 60: 104-111.

El Leithy, Tamer (2005), Coptic Culture and Conversion in Medieval Cairo, 1293-1524, PhD dissertation, Princeton University.

65 Tillier 2014. 
El Shamsy, Ahmed (2013), The Canonization of Islamic Law. A Social and Intellectual History, Cambridge: Cambridge University Press.

Fahmī, Muḥammad 'A. R. (1972-1973), “Wathā’iq li-l-ta'āqud min fajr al-Islām”, Majallat al-Majma' al-'Ālī al-Mișrī 54: 1-58.

Foss, Clive (2009), “Egypt under Mu'āwiya. Part I: Flavius Papas and Upper Egypt”, Bulletin of the School of Oriental and African Studies 72: 1-24.

Foss, Clive (2009), “Egypt under Mu'āwiya. Part II: Middle Egypt, Fusțāṭ and Alexandria”, Bulletin of the School of Oriental and African Studies 72: 259-278.

Frantz-Murphy, Gladys (1981), "A Comparison of Arabic and Earlier Egyptian Contract Formularies. 1: The Arabic Contracts from Egypt (3rd/9th-5th/11th centuries)”, Journal of the Social and Economic History of the Orient 40: 203-225; 355-356.

Frantz-Murphy, Gladys (2001), Corpus Papyrorum Raineri XXI. Arabic Agricultural Leases and Tax Receipts from Egypt 148-427 AH/756-1035 AD, Vienna: Brüder Hollinek.

Gagos, Traianos / van Minnen, Peter (1994), Settling a Dispute: Toward a Legal Anthropology of Late Antique Egypt, Ann Arbor: University of Michigan Press.

Gonis, Nikolaos (2004), “Another Look at Some Officials in Early 'Abbāsid Egypt”, Zeitschrift für Papyrologie und Epigraphik 149: 189-195.

Grohmann, Adolf (1952), From the World of Arabic Papyri, Cairo: al-Ma'aref Press.

Kelly, Benjamin (2011), Petitions, Litigation, and Social Control in Roman Egypt, Oxford: Oxford University Press.

Khan, Geoffrey (1993), Bills, Letters and Deeds: Arabic Papyri of the $7^{\text {th }}$ to $11^{\text {th }}$ Century, London: Nour Foundation.

Khan, Geoffrey (1994), "The Pre-Islamic Background of Muslim Legal Formularies”, ARAM 6: $193-224$.

Khan, Geoffrey (2006), “Newly Discovered Arabic Documents from Early Abbasid Khurasan”, in: Petra M. Sijpesteijn et al., eds., From al-Andalus to Khurasan. Documents from the Medieval Muslim World, Leiden: E. J. Brill, 199-216.

Lamoreaux, John C. (1995), “Episcopal Courts in Late Antiquity”, Journal of Early Christian Studies 3: $143-167$.

Legendre, Marie (2016), "Neither Byzantine nor Islamic? The Duke of the Thebaid and the Formation of the Umayyad State", Historical Research 89: 3-18.

MacCoull, Leslie S. B. (2009), Coptic Legal Documents. Law as Vernacular Text and Experience in Late Antique Egypt, Tempe: Arizona Center for Medieval and Renaissance Studies.

Mikhail, Maged S. A. (2013), From Byzantine to Islamic Egypt, London/New York: I. B. Tauris. Morelli, Federico (2010), Corpus Papyrorum Raineri XXII. Griechische Texte XV. L'archivo di Senouthios Anystes e testi connessi: lettere et documenti per la costruzione di una capitale, Berlin: Brüder Hollinek.

Morelli, Federico (2014), “SB XXIV 16219 Una lettera di Atias in difesa di una donna”, Tyche 29: $95-98$.

Palme, Bernhard (2007), “The Imperial Presence: Government and Army”, in: Roger S. Bagnall, ed., Egypt in the Byzantine World 300-700, Cambridge: Cambridge University Press, $244-270$.

Rāg̀ib, Yūsuf (1991), "La plus ancienne lettre arabe de marchand”, in: Yūsuf Rāg̀ib, ed., Documents de l'Islam médiéval: nouvelle perspective de recherche, Cairo: IFAO, 1-10. 
Reinfandt, Lucian (2010), "Law and Order in der frühen islamischen Gesellschaft. Strafverfolgung in Ägypten und Palästina nach der arabischen Eroberung (7.9. Jahrhundert)", in: Robert Rollinger et al., eds., Interkulturalität in der Alten Welt. Vorderasien, Hellas, Ägypten und die vielfältigen Ebenen des Kontakts, Wiesbaden: Harrassowitz Verlag, 655-682.

Reinhardt, Karl (1897), “Eine arabisch-koptische Kirchenbann-Urkunde”, in: Aegyptiaca. Festschrift für Georg Ebers, Leipzig: Wilhelm Engelmann, 89-91.

Scheerlinck, Eline (forthcoming), “'Like Oil in Their Bones”. Banning and Cursing by Episcopal Letter beyond Late Antiquity”, in: Mattias Brand and Eline Scheerlinck, eds., Religious Identifications in Late Antique Papyri.

Schiller, Arthur A. (1968), "The Budge Papyrus of Columbia University”, Journal of the American Research Center in Egypt 7: 79-117.

Sijpesteijn, Petra M. (2007), "The Arab Conquest of Egypt and the Beginning of Muslim Rule”, in: Roger S. Bagnall, ed., Egypt in the Byzantine World 300-700, Cambridge: Cambridge University Press, 437-459.

Sijpesteijn, Petra M. (2012), “Seals and Papyri from Early Islamic Egypt”, in: Ilona Regulski et al., eds., Proceedings of the International Workshop on "Seals and Sealing Practices from Ancient Times till the Present Day. Developments in Administration and Magic through Cultures", Cairo, Netherlands-Flemish Institute in Cairo, Leuven: Peeters.

Sijpesteijn, Petra M. (2013), Shaping a Muslim State: The World of a Mid-Eighth-Century Egyptian Official, Oxford: Oxford University Press.

Sijpesteijn, Petra M. (2016), “Delegation of Judicial Power in Abbasid Egypt”, in: Maaike van Berkel, Léon Buskens, and Petra M. Sijpesteijn, eds., Legal Documents as Sources for the History of Muslim Societies. Studies in Honour of Rudolph Peters, Leiden: E. J. Brill, 61-84.

Sijpesteijn, Petra M. (2018), "Policing, Punishing and Prisons in the Early Islamic Egyptian Countryside (642-900 CE)", in: Alain Delattre, Marie Legendre, and Petra M. Sijpesteijn, eds., Authority and Control in the Countryside: From Antiquity to Islam in the Mediterranean and Near East (6th-10th Century), Leiden \& Boston: Brill: 543-584.

Simonsohn, Uri (2011), A Common Justice. The Legal Allegiances of Christians and Jews under Early Islam, Philadelphia: University of Pennsylvania Press.

Steindorff, Georg (1892), “Eine koptische Bannbulle und andere Briefe”, Zeitschrift für Ägyptische Sprache und Alterthumskunde 30: 37-43.

Till, Walter C. (1938), “Eine koptische Alimentenforderung”, Bulletin de la société d'archéologie copte 4: 71-78.

Tillier, Mathieu (2016), “Arbitrage et conciliation aux premiers siècles de l'Islam: théories, pratiques et usages sociaux”, Revue des mondes musulmans et de la Mediterranée 140: $27-52$.

Tillier, Mathieu (2012), Histoire des cadis égyptiens (Aḩbār quọāt Miṣr), Cairo: Institut français d'archéologie orientale.

Tillier, Mathieu (2013), “Du pagarque au cadi: Ruptures et continuités dans l'administration judiciaire de la haute-Égypte (ler-IIIe/VIIe-IXe siècle)", Médiévales 64: 19-36.

Tillier, Mathieu (2014), “Le temps de la justice aux premiers siècles de l'islam”, Revue des mondes musulmans et de la Méditerranée 136: 71-88.

Worp, Klaas A. (1982), “Nochmals der Notar Anup. Eine Byzantinische Bürgschaftsurkunde”, Zeitschrift für Epigraphik und Papyrologie 47: 285-290. 